\title{
3
}

\section{Australia and the Keynesian Revolution}

\begin{abstract}
Alex Millmow
When the Nobel prize-winning economist Joe Stiglitz visited Australia in 2010 he commended the Rudd Government's policy response to the Global Financial Crisis as a proper and effective pre-emptive measure. The stimulus, which staved off any creeping sign of recession, bore a considerable Treasury imprint; and it could be said that the official family of economic advisers, that is, the Treasury and the Reserve Bank of Australia, were in their concerted action never so Keynesian in practice. It is appropriate then to visit the Keynesian revolution in post-war Australia recalling that three of the mandarins, Roland Wilson, John Crawford and H.C. 'Nugget' Coombs, were professionally trained economists. Moreover, as J.K. Galbraith reminds us, the Keynesian revolution was really a 'mandarin revolution', that is, an intellectually powered one.

The romanticist and rationalist account usually attributes the arrival of the Keynesian revolution in Australia to the outbreak of the Second World War and the enforced mobilisation of resources. While Keynes wanted America to be the laboratory where his new doctrines could be tested, it is a little known fact that it was Australia that proved the true testing ground. Australian economists were ahead of their counterparts elsewhere in adopting Keynes' insights into demand management, not just to prosecute the war but also to avoid any reoccurrence of depression. It was in November 1939, though, that a Keynesian revolution in economic policy may be said to have 'arrived' in this country. Like all revolutions it was to become compromised and sidetracked by political exigencies. One figure who saw this process was the New Zealand-born economist Douglas Copland, whose dissenting views on post-war economic management punctuate the second half of this chapter.

Usually the so-called 'golden age' of Keynesian economic management is associated with the years 1945 to 1973, after which the Keynesian consensus became unstuck as the anchors underpinning it came loose. However, as Selwyn Cornish has pointed out, even the first seven years of that period were pockmarked by policy error, aberrations and a reluctance to use market-friendly
\end{abstract}


policies. ${ }^{1}$ This chapter adopts Cornish's approach and extends it to the 1960 credit squeeze and beyond, showing how acceptance of Keynesian economic management always came second to politics.

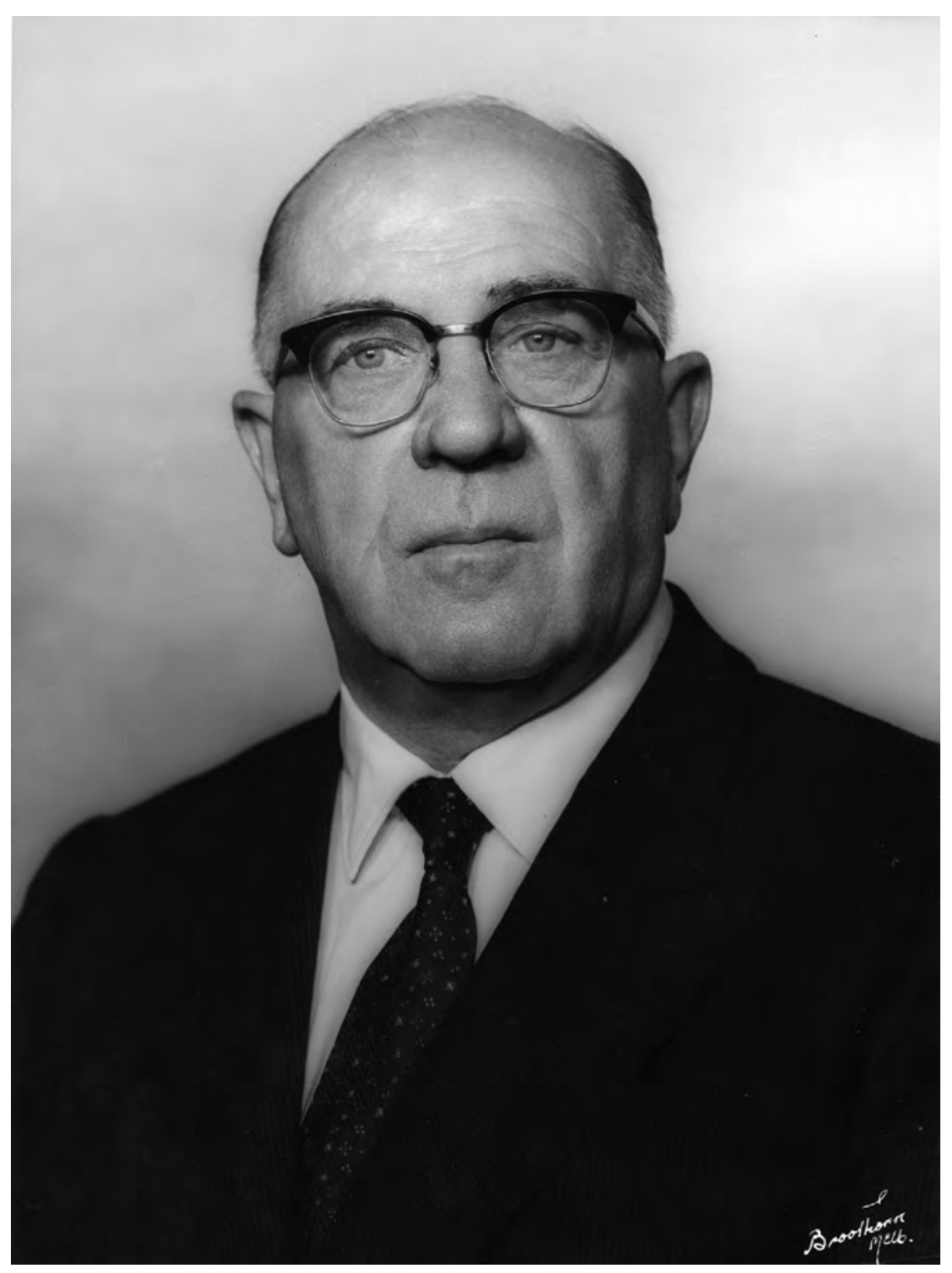

\section{Sir Douglas Berry Copland, 1951}

Source: National Library of Australia, nla.pic-vn3942118

1 S. Cornish, 'The Keynesian Revolution in Australia: Fact or Fiction', Australian Economic History Review, 33, no. 2 (1993). 
This chapter is divided into four parts. The first provides a little detail on the small Australian economics community that spearheaded the acceptance of Keynes' doctrine on national income determination. The second part concerns how economists received Keynes and sought to impart change in the policy settings up to the early stages of the Second World War. It briefly describes the mobilisation of economic expertise into the Australian war effort - a mobilisation of economics expertise far ahead of Britain and America at the time. The third and fourth parts address post-war economic issues using and examining, for instance, the debate about full employment but from the view of Copland who had, since war's end, been largely excluded from policy making circles. The last part of the chapter offers a retrospective about the revolution in economic practice.

\section{The inter-war Australian economics community}

The leading economists of the inter-war period were an extraordinary bunch of men. The two most significant figures, Douglas Copland and L.F. Giblin, were larger than life. Giblin was described as having the body of a prizefighter and being a natural leader of men. There have, in the last few years, been two monographs celebrating their contribution. One, Giblin's Platoon, celebrates the rise of the Australian economics profession through the lens and activities of Giblin. $^{2}$

The other monograph, The Power of Economic Ideas, delves into the origins of macroeconomic management largely through the lens of Copland who was Foundation Dean of the Faculty of Commerce at the University of Melbourne. ${ }^{3}$ Only he had formal, systematic training in economics. ${ }^{4}$ Copland noted how his contemporaries were free of academic reserve and willing to enter into the fray of public debate. He would later remark that the post-Second World War generation of economists did not have the same gusto to enter into the fray of policy making. ${ }^{5}$ This was partly because the Commonwealth Government had established its own pool of economic expertise after $1945 .^{6}$

\footnotetext{
2 W. Coleman, S. Cornish and A. Hagger, Giblin's Platoon: The Trials and Triumph of the Economist in Australian Public Life (Canberra: ANU E Press, 2006).

3 A.J. Millmow, The Power of Economic Ideas: The Origins of Macroeconomic Management in Australia (Canberra: ANU E Press, 2010).

4 S.J. Butlin, 'The Hundredth Record', Economic Record, 42, no. 100 (1966), 509.

5 D.B. Copland, Inflation and Expansion (Melbourne: Cheshire, 1951), 9-10.

6 M. Corden, Australian Economic Policy Discussion: A Survey (Melbourne: Melbourne University Press, 1968), 58-9.
} 


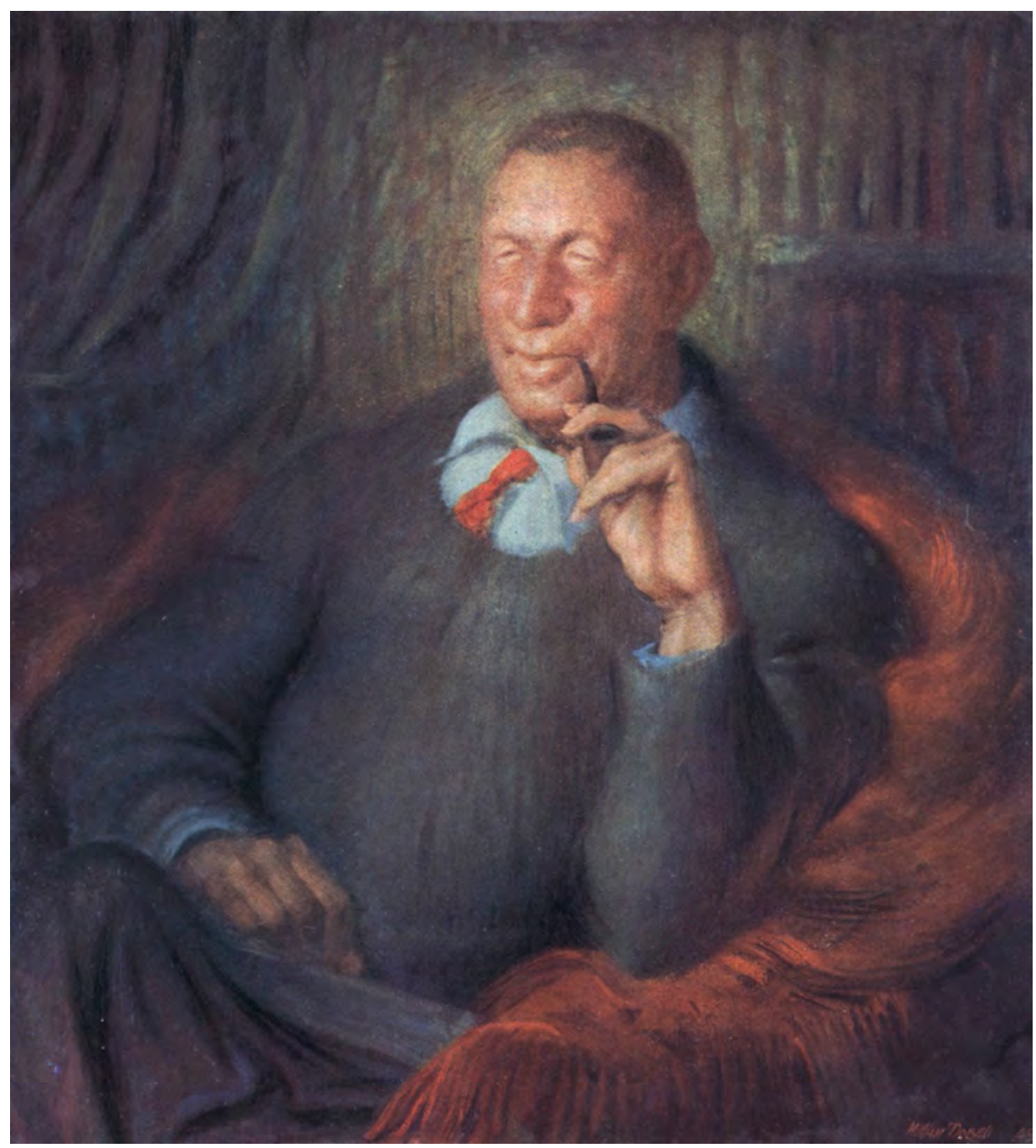

\section{Professor L.F. Giblin, portrait by Sir William Dobell, c1945}

\section{Source: University of Melbourne Archives, UMA/I/1026}

While the inter-war generation of economists were great practitioners they were not renowned as theoretical innovators. The genius of inter-war Australian economists came in adopting theoretical tools to deal with these problems. Giblin summed up the axioms and values that characterised his contemporaries:

In Australia economists are a peculiar tribe. Rarely are they nourished by the pure milk of the word. Mostly they have been advisers to governments for many years - permanently or intermittently, publicly or privately. Governments do not love them but are inclined to believe 
them honest ... They are frequently more practical and realistic than businessmen ... They are resented, of course, by sectional business interests. The word of complaint or abuse is 'academic'; but, in truth, they are the least academic of God's creatures. ${ }^{7}$

Following the relative success of the Premiers' Plan, Keynes invited Copland to give the 1933 Marshall lectures at Cambridge. As the 'public relations man of Australian economics', Copland reported on the rehabilitation of Australia from near bankruptcy to one of the first economies to recover from the Depression. ${ }^{8}$ The process had been helped by having four key economic agencies coming under the influence of independent economic advice. One of those tribunals, the Conciliation and Arbitration Court, ordered the emergency wage cut of 10 per cent in 1931 .

Copland was the expert witness appointed by the Court to urge the necessity for wage cuts. This advice confirmed Labor opinion that Copland was in the pay of employers and the banks. And they would never let Copland forget it. In the post-war years Arthur Calwell and Bert Evatt made reference to it, though the former, more kindly, could not believe how much Copland had changed. This was a Copland trademark: to change his position and be open to charges of inconsistency.

By the mid-1930s Australia was regarded by one Indian economist, B.P. Adarkar, as 'the Utopia of practical economists' because problems like wage fixation, tariff setting, monetary management and federal finance were dealt in a scientific way by experts and governments working together. ${ }^{9}$ The English economic historian, C.R. Fay, congratulated his Australian counterparts for their 'good fortunes to live in a country where economists are occasionally heeded.' ${ }^{10}$

Australian economists did not commit the same mistake as their American counterparts in 1937 by advising the federal government to cut spending now that recovery was underway. The former prime minister and treasurer,

\footnotetext{
7 T. Hytten, 'Giblin as an Economist', in D.B. Copland, ed., Giblin; The Scholar and the Man (Melbourne: Cheshire, 1960), 96.

8 N. Cain, 'Australian Keynesian: The Writings of E.R. Walker', Working Papers in Economic History, 13 (Canberra: Australian National University Press, 1983), 2.

9 C. Goodwin, The Image of Australia (Durham: Duke University Press, 1974), 236. In a letter to Keynes in November 1941 the English-born and raised economist, Colin Clark, explained how he had fallen in love with Queensland: 'When you leave England for Australia you get a strange feeling you have somehow jumped ten years into the future, and when you come to Queensland you jump ten years further. Queensland is a predominantly rural and small enterprise economy, with a very equalitarian distribution of income and property, very generous social services, compulsory Trade Unionism, and all matters of wages hours and working conditions judicially controlled by the Arbitration court, which now has such prestige that both sides always accept its decision'. C. Clark to J.M. Keynes, 10 November 1941, University of Queensland Library, Colin Clark Papers, UQFL87.

10 Goodwin, The Image of Australia, 236.
} 
R.G. Menzies, always wary about economics, dryly observed that '[i]n the economic history of the last fifteen years nothing will be more notable than the rise in influence and authority of the professional economist ${ }^{\prime}{ }^{11}$

Giblin encouraged the Commonwealth Public Service to recruit more graduates instead of being a repository for returned servicemen. The growing professionalisation of economics was matched by gradual placement of economists within the CPS. The first two appointees had been outstanding academic economists. Leslie Melville joined the Commonwealth Bank in 1931 and, in the following year, Roland Wilson joined the Treasury. Coombs, a doctoral graduate of the London School of Economics, found employment in the Commonwealth Bank working under the supervision of Melville.

The rising Turks of the Australian economics profession were all more receptive to Keynes' General Theory than their older colleagues. Names like Trevor Swan, Heinz Arndt, Peter Karmel, Gerald Firth and Richard Downing come to mind. The most eminent, though, must be Coombs and Wilson. The Keynesian revolution would, in J.E. King's words, 'conquer Australia like the Spanish inquisition'. ${ }^{12}$

Certainly, by 1939, Melville and Downing would independently recall that the small corps of economists in Australia were all Keynesian in policy persuasion, if not analytical framework. ${ }^{13}$ It was helped in that process both by Keynes' dealings with Copland and Giblin and also by having two of his associates, Colin Clark and Brian Reddaway, spend time in the Antipodes. Reddaway's thoughtful and incisive précis of what Keynes was saying became the first published academic review of The General Theory. Clark had gone to Australia in 1937 on a visiting lectureship but was expected to return to Cambridge to head a department of applied economics. When Keynes asked when Clark would be coming home, he could only sing of the attraction of remaining in Australia: 'People have minds which are not closed to new truths ... and with all the mistakes Australia has made in the past, I still think she may show the world, in economics ... in the next few years.' ${ }^{14}$ They were poignant words.

\footnotetext{
11 R.G. Menzies, 'The Australian Economy During War', Joseph Fisher Lecture in Commerce (Adelaide: Hassell Press, 1942), 6.

12 J.E. King, 'Notes on the History of Post-Keynesian Economics in Australia', in P. Arestis, G. Palma and M. Sawyer, eds, Capital Controversy: Post-Keynesian Economics and the History of Economic Thought (London: Routledge, 1997), 298.

13 S. Cornish, 'The Keynesian Revolution in Australia Fact and Fiction', Australian Economic History Review, 33, no. 2 (1993), 19; R.I. Downing, 'Review of M. Keynes (ed.), Essays on John Maynard Keynes', Economic Record, 52, no. 137 (1972), 11-12.

14 J.M. Keynes, in D. Moggridge, ed., The Collected Writings of John Maynard Keynes, Vol. 27, Employment and Commodities (London: Macmillan, 1981), 808.
} 


\section{War finance}

The last year of peacetime in Australia was marked by difficult economic choices and political turbulence. The necessity to divert resources into defence as the security environment grew darker was jeopardised by the federal structure of government and traditional ideas about public finance. By the end of 1939 there came, however, a moment of economic revelation. As Copland later styled it:

The lesson of the war is unmistakable in its demonstration that, given a clear and generally accepted objective, we can erect an economic structure far superior to that which we knew during the dark days of the thirties. ${ }^{15}$

In 1939, Australia smoothly switched to a total war economy because economists serving on a key advisory committee known as the Financial and Economic Committee were uncommonly influential. Formed in late 1938, the F and E Committee under Giblin's leadership convinced the then Acting Federal Treasurer, Percy Spender, that, before resorting to taxes and borrowing expedients, the war effort could be met by putting all human and physical resources to work.

Coombs was adamant that the committee gave 'economic planning of the war' a Keynesian pedigree. The idea for the committee came from Wilson. It was the realisation of his 'central thinking agency' that he had spoken of in $1934 .{ }^{16}$ Wilson had in mind a 'small thinking committee to which all sorts of problems could be submitted for general advice. ${ }^{\prime 17}$

The committee's primary task would be to advise the treasurer and his department. Eventually this would amount to the committee challenging the Treasury's orthodox canons of war finance. While Giblin is credited with leading the way, some influence should be credited to E.R. Walker who had written a book on war economics. Singing its praises, Copland said the 'great virtue' of Walker's book was that it got 'behind the veil of money' and put the defence problem 'in real terms' ${ }^{18}$

Copland reckoned that a war effort of 15 per cent of resources was possible before any strain on resources would emerge. Australian economists advised the government therefore to shepherd resources by borrowing until the economy reached full employment. This was around the same time Keynes applied the General Theory framework to war economics in How to Pay for the War (1940).

15 D.B. Copland, The Road to High Employment (Melbourne: Angus \& Robertson, 1945).

16 W.G.K. Duncan, National Economic Planning (Melbourne: Angus \& Robertson, 1934).

17 G. Whitwell, The Treasury Line (Sydney: Allen \& Unwin, 1986), 2.

18 D.B. Copland, 'News and notes', Economic Record, 15 (1939), 230-1. 
In short, Spender assimilated a physical resources view as distinct from a monetary view. It was Giblin, then, who encouraged Spender to attempt more with fiscal policy. Giblin demonstrated how Australia, with 10 per cent unemployment, could painlessly increase its defence budget without facing resource pressures. Instead of a heavy-handed resort to economic controls that would intimidate business, Giblin felt that expenditure could be raised through credit expansion. Convinced, Spender raised the matter with Menzies, highlighting how the financial costs of the war effort could be lightened by putting the unemployed back into work. While the unemployed had, hitherto, been a state matter, Spender believed the initiative 'would not only be good politics on our part, but sound economics, if we take the lead in this matter' ${ }^{19}$

Spender took Giblin's proposal to Cabinet and announced, in dramatic words, 'One of the objectives of our present policy is to restore and increase the national income. This will enable us to divert resources to defence without encroaching unnecessarily on existing standards of consumption'.$^{20}$ Spender made it clear in a submission to Cabinet how borrowing for defence would be from the central bank thus sparing private enterprise from a greater tax burden. Once capacity and full employment were reached, however, taxation would assume its rightful duty and prevent any inflation. This 'changeover' point was projected to occur by May 1940.

Cornish has identified this as the moment when a Keynesian revolution in economic policy 'arrived' in Australia. An English newspaper hailed Spender's budget as 'the answer to an economist's prayer' ${ }^{21}$ Until then, at the official policy level, there had been little recognition of expanding economic activity by bringing idle resources into circulation. It revolved around the necessity of how quickly, and the means by which, to increase military spending. Raising taxes, issuing public loans or recourse to credit finance, that is, budget deficits, would disrupt economic activity. This spelt sacrifices not only to programs but also political reputations. Indeed, the Commonwealth Bank, then Australia's central bank, recycled a version of the British Treasury's view; namely, that using resources for defence needs, even amidst 10 per cent unemployment, would reduce the amount of consumer goods that could be produced when the economy recovered.

Before the outbreak of the war Copland had wanted the same array of economic controls Nazi Germany had. With the outbreak of war he had his wishes partly granted. Menzies asked him to come to Canberra as Commonwealth Prices Commissioner and also as economic consultant to the prime minister. The need

19 Cited in Millmow, The Power of Economic Ideas, 263.

20 Ibid., 263.

21 Cited in P. Spender, Politics and a Man (Sydney: Collins, 1942), 45. 
for price control was immediate, albeit taking place in an environment of suitable macroeconomic policies. The need for price control was urgent if production was to be directed to areas of greatest national need rather than to areas of greatest profit. As Prices Commissioner, Copland recognised that a leading problem of price control was that of limiting increases in the price structure to the unavoidable increases in costs while preventing, as far as possible, a general upward movement in prices brought about by the operation of outside influences. He saw that a general increase in the prices of basic commodities would cause a rise in the cost of living and a consequent rise in the basic wage, which was automatically adjusted to the cost of living.

With the coming to office of the Curtin Labor Government, and the entry of Japan into the conflict, Australia entered a more difficult and demanding stage of the war. The government resorted to planning and regulations, and newly created government departments, headed by the likes of Wilson, superseded the work of the $\mathrm{F}$ and $\mathrm{E}$ Committee. As the Japanese threat receded, planning for post-war reconstruction received increasing attention.

\section{The post-war challenge}

There was a general fear that the end of hostilities would see, after a brief postwar boom, the return of the slump. It gave urgency to the task of preventing a rerun of the 1930s, with governments undertaking to make elimination of unemployment 'a fundamental aim' of economic policy. Australia reached the crowning glory of Keynesianism when the Chifley Government presented the White Paper on Full Employment. As Selwyn Cornish has detailed, the document took an inordinate amount of redrafting with plenty of material from economists, along with Curtin and Chifley. The White Paper was a more circumspect and considered document than its British counterpart, with clauses on fiscal balance, the mobility of resources, productive efficiency, wage stability, stabilisation by government spending and concerns about the external account. The successful management of war finance alleviated concerns about the efficacy of fiscal policy to fulfil the promise placed on it.

Memories of widespread unemployment in the inter-war years cut deeply. Australian economists invested their hopes in the White Paper and the political authorities observed the target. Indeed, the economic history of the post-war era was that the authorities were too zealous in pursuing it. The reluctance to consider checking aggregate demand policies might have had something to do with anxieties about the return of depression. There was an element of a depression mentality in the air. It is astonishing to recall that the Menzies 
Government nearly lost office because it let unemployment reach 3.1 per cent by 1961-62. In contrast, the collective consciousness held little fear of severe inflation yet it became the prevailing problem during the Keynesian era.

Inflation had been contained during the war years by a comprehensive prices and rationing system. The Labor Government had allowed excessive liquidity to build up in the economy which was kept in check by controls on prices, wages and capital. This problem carried over into the peacetime economy with economic activity potentially excessive. The post-war economy was marked, therefore, by high levels of economic activity, full employment and inflation. Inflation was suppressed by retaining the wartime administrative controls including price and capital controls.

The Chifley Government was reluctant to engage in containing demand by fiscal and monetary means even though the White Paper had envisaged their use. The 1948-49 budget was stimulatory and involved capital spending on infrastructure to further development. The Menzies Government also embraced developmentalism, a mindset that was promoted by the Treasury. It was only after the inflationary boom of 1951 that both the Treasury and the Commonwealth Bank persuaded the Menzies Government to cut back outlays.

The tendency, though, towards maintaining the economy at a high pitch of activity was the outstanding pattern of macroeconomic policy during the Keynesian era. It was compounded by commitments to a high rate of immigration and development without resorting to credit restrictions and import controls to counteract inflationary pressures and balance of payments problems. Neither the electorate nor politicians found the prospects of budget deficits too galling in the early post-war years. The prevailing political milieu was to oppose raising taxes and to regard budget surpluses as the opportunity to reduce taxation. Perhaps it was reasoned that with rationing still in tow there was enough austerity being administered. The Chifley Government also had ideological concerns about using interest rates to choke off excessive aggregate demand. The Menzies era, too, was also marked by a perceptible reluctance to use market controls to fine-tune aggregate demand.

Overall, the political economy of the first 15 years after the war was one of continuous economic growth coupled with inflation and pressures upon the external account. Coombs identified that there was both political resistance and interest group resistance to undertaking the necessary deflationary measures that the Australian economy needed. The short life of the electoral cycle reinforced the reluctance to act just as officials were hesitant about advice unacceptable to ministers. In the same vein, Gerald Firth spoke in 1951 of an asymmetry problem, in that every interest group backed expansion but there was resistance 
to confronting inflation. ${ }^{22}$ It partly derived from the unwillingness of most Australian economists during the post-war reconstruction era to speak about the dangers of inflation. Only the Menzies Government in 1951 and again in 1960 was prepared to bite the bullet but only after the Treasury and Commonwealth Bank were pulling in concert to curb a boom.

\section{Keynes and the Australian Keynesians}

Not all economists in Australia adhered to the early post-war consensus about Keynesianism. The old guard were not totally swept away by The General Theory as the young were. There was the added question of interpreting Keynes and, on that note, the difference between Keynes and the Keynesians. There was Keynes' famous jibe that, after attending a dinner party in Washington with American Keynesians, he recollected 'I was the only non-Keynesian there'. Keynes had told Hayek that he would put the young heretics in their place but he did not live long enough to do so. Nor did Keynes get round to writing a sequel to The General Theory.

Giblin was worried that full employment would trigger a wages problem and asked Keynes about it. Keynes demurred, saying the control of wages at full employment was ultimately 'a political problem' ${ }^{23}$ Keynes was equally concerned about avoiding inflation at full employment as he was about avoiding another slump. He felt that the workers and trade unionists would show a degree of community-mindedness.

James Brigden's reaction, later encapsulated in a short and querulous article in the Economic Record, noted how credit expansion would result in rising wage costs as full employment was approached. The problem was that there was 'no coordination between wages policy and finance policy' to prevent wage inflation from occurring. Consequently, Brigden concluded that if credit expansion and, thus, full employment, were pursued, there would have to be controls upon labour, foreign exchange and investment. ${ }^{24}$

In Brisbane, Colin Clark, director of the Queensland Bureau of Industry, state statistician and economic adviser to the Queensland Treasury, was working on the thesis that too much spending by the federal government ultimately meant inflation. The idea had come from Premier Hanlon, who was concerned that the

\footnotetext{
22 G.G. Firth, 'Disinflation in Australia: A Democratic Dilemma', Paper presented to the ANZAAS Conference 1951, Brisbane, Queensland.

23 Cited in A. Millmow, 'The Evolution of John Maynard Keynes' Wage and Employment Theory, 19201946', History of Economics Review, 71 (1992).

24 J.B. Brigden, 'The credit theory of full employment', Economic Record, 15 (1939).
} 
mooted post-war expenditures on social goods and nationalisation reminded him that it had been excessive taxation that had been the undoing of empires and countries in the past.

Clark investigated and subsequently deduced that the maximum rate of taxation was 25 per cent of net national product and submitted his research to the Economic Journal, which Keynes edited. If a nation did engage in over taxing, he predicted that, after some lag, rising inflation would result. In other words, it was high and rising taxation that stimulated rising prices; and rising government expenditure was the main cause for this rising taxation. ${ }^{25}$

Clark was adamant that Keynes agreed with his contention and that he had been working on the matter when he had died in April 1946. Clark never deviated from being 'Mr. 25\%' ${ }^{26}$ Whether Keynes would have stayed constant with the principle is debatable given his penchant to change his mind when the circumstances changed. Clark, who had worked with Keynes, would later write that his mentor was a liberal who believed in the free market 'because it provides the maximum possible decentralisation of economic decision' ${ }^{27}$

The most vocal dissident to the Keynesian crusade, though, was Copland. In his Godkin lectures, given at Harvard in 1945, Copland focused upon the eternal problem of the relation of state control to private enterprise or, more broadly, the relationship between the private and public sectors. Copland contended that the pre-war economy failed to operate in the best interests of the community at large, that it could not avoid depressions, and that it would not employ all available factors in the long run. To stabilise the economy and ensure a certain measure of security for all, he continued, it would be necessary for the nation as a whole to engage in public investment and not be fearful of national debt. While praising the power of entrepreneurial talent, Copland argued that some degree of social control, expressed through a large public sector, would give capitalism a more benign, ordered traverse. Copland, however, was not enamoured of full employment, preferring high employment.

Unlike many others in the profession, Copland quickly realised that it was rapid, almost unnerving, economic progress that would be the normal state of affairs for market economies, not stagnation of the pre-war era. Contrary to fears of a postwar depression, the new era was marked by astonishing rates of technological and economic growth for most countries, none more so than Australia, which would grapple with a bold development and migration program in the post-war

\footnotetext{
25 A. Millmow, 'Colin Clark and Australia', History of Economics Review, 56 (2012).

26 A. Millmow, 'Mr. 25\%', Australian Financial Review, 2 July 2010.

27 C. Clark, 'Keynes and Others: A Personal Memoir' (1982), 18, University of Queensland Library, Colin Clark Papers, UQFL87.
} 
period. Australia, though, found itself in the early post-war period beset by bouts of inflation and external deficits, which led to corrective action followed by another spurt of expansionism.

As the first vice-chancellor of The Australian National University, Copland was not expected to engage in public debate about economic management but no one dared silence him. His views rubbed hard against those of the 'inside' economists. Copland, however, was not the only isolated voice. Heinz Arndt has argued that in the post-war era, until the 1970s, economic policy was conducted by the inside economists with academic voices shut out. He goes on to remark:

The Commonwealth Government in the 1950s and 1960s had the advice of better economists inside than were to be found outside - seven of the best, as it happened all men of good minds but short stature, were nicknamed 'Mr Menzies's Seven Dwarfs'. They did not feel the need for outside help, so that university economists were more remote from government than in most other western countries. ${ }^{28}$

There was also a chasm in how economists within the Department of PostWar Reconstruction, headed by Coombs, interpreted the 'new economics' of Keynes and how Copland did. Copland was seen as somewhat detached from the great post-war 'crusade' of Keynesian economic thought and practice led and propagated by Coombs. ${ }^{29}$ There was undoubtedly some animus between the two that sprang from the bureaucratic power struggle during the war years. While he was economic consultant to the prime minister during the war, Copland had never been part of Chifley's circle of advisers. For his part, Coombs felt Copland was a rather pedestrian economist.

Copland wanted to participate in the 'dynamizing' of Keynes' conceptual revolution. For Australia, this meant channelling resources into investment, rather than consumption; of having capacity-building rather than full employment. Copland lamented that 'Keynes didn't live to castigate his followers who turned his theory of full employment into one of economic stability and security at all costs' ${ }^{30}$ Copland would further maintain that the Chifley and Menzies governments did not address the full criteria and economic challenges set out in the White Paper on Full Employment. He bemoaned that post-war Australia was not meeting the economic objectives contained in Part IV of the White Paper, which covered questions like fiscal balance, the mobility of resources, productive efficiency, wage stability, stabilisation by government spending and concerns about the external account. Coombs and Walker felt a

28 'Antipodean Economics' (1987), National Library of Australia, Papers of Heinz Wolfgang Arndt, 1933-2002.

29 H.C. Coombs, Trial Balance (Melbourne: Sun Books, 1981).

30 D.B. Copland to Michael Barkway, 15 February 1961, Copland Papers, National Library of Australia (NLA) MS 3800, Box 11, Series 1, Folder 88. 
state of full employment was more likely with extensive planning. Copland felt that this was unnecessary and that the maintenance of high employment would not require any extensive state authority over the prerogative of capital, only a degree of regulation.

\section{The ragtime of Australian economic policy, 1948-1952}

When Copland became vice-chancellor of The Australian National University in 1948, he told a businessman how he 'was appalled at both the state of the economy and the state of the mind of economists'.$^{31} \mathrm{He}$ campaigned to get Australian economic policy on a more fundamental footing and waged a critique of 'the younger brethren' of economists in a series of speeches and provocative articles. The earliest of these articles were designed to make 'a splash' in order to further a political ambition as a prospective Senate candidate for the Coalition in the forthcoming election. Apart from this, however, the string of commentaries mirrored his deep concerns about the orientation of the Australian economy and the rubric of economic policy. He informed Menzies there was a 'deplorable state of affairs' in Canberra with the Chifley Government struggling with postwar demands on the economy. ${ }^{32}$ Copland later told the English economist, Edith Penrose, that the period from 1948 to 1952 was 'the ragtime of Australian economic policy' - a period of immense policy error. ${ }^{33} \mathrm{He}$ had a point. Australia would endure aberrations like an attempt at bank nationalisation, coal strikes, raging inflation, a needless devaluation against the American dollar, relaxation of physical controls and then their reimposition, and a boom and bust within the space of five years.

Back to Earth in Economics: Australia 1948 was a critique of the supposed Keynesianism practised by Australian economists. They were to be 'brought back to earth'. In short, Copland felt that the post-war economic forecasts had been much too dire about the Australian economy and that the subsequent 'obsession with security' and pumping up aggregate demand was no basis on which to develop the nation. That is, there should be an equal stress upon raising the rate of economic growth and augmenting the supply side of the economy. There would be difficulties, too, he noted, if the government had to curtail expenditure to contain inflation.

31 D.B. Copland to G. Foletta, 10 May 1954, Copland Papers, NLA MS 3800, Box 8.

32 D.B. Copland to R.G. Menzies, 9 January 1949, Copland Papers, NLA MS 3800, Box 8.

33 D.B. Copland to E. Penrose, 28 November 1955, Copland Papers, NLA MS 3800, Box 9. 
Copland also set out to dispense with the 'depression psychology' permeating the Australian economic policy establishment, which held back the embrace of growth and development. To develop his case, Copland took the line that the post-war boom was more a case of accident than design, that is, full employment was basically inevitable. It had been achieved by creating a business environment conducive to an increase in private investment above pre-war levels. While there was a post-war investment boom it was not, Copland argued, 'a good ground on which to claim the success of a full employment theory of full employment' when that condition was inevitable. The main reason for the buoyant level of economic activity was due to the legacy of the war economy, demands of reconstruction and expansion of universal welfare.

There was also the ephemeral fortune of high export prices. Copland's argument anticipated that of R.C.O. Matthews' controversial paper in 1968 that the reason why unemployment had been low in the post-war years in Britain and elsewhere was a prolonged investment boom as countries made good on the war damage and that 'the decline of unemployment ... is to a large extent not a Keynesian phenomenon at all'.$^{34}$ Copland also wanted to deride the idea that, with simple demand management, Australia was bound for a 'golden age' in economic performance when, in fact, the objectives of post-war reconstruction were 'not being attained'. Copland feared that Australian policy-makers were becoming complacent with the return of good times, which masked underlying weaknesses within the economy. Post-war advantages had been frittered away by labour unrest, the wasting of record high export earnings and lower taxes. Nor was Australia investing sufficiently in key industries to secure vigorous and sustained growth. The culprit was the doctrine of over-full employment - that is, more jobs than people to fill them - which prevented resources flowing to the most productive ends and enticed absenteeism, overmanning and labour indiscipline. There were shortages of coal and steel in 1948, which gave the lie to the government's obsession that maintaining full employment was sufficient to maintain productive well-being. More importantly, the doctrine of full employment lulled policy-makers into a false sense of security that they had the means to handle exogenous economic shocks. Copland was concerned that the veneer of prosperity made policy-makers blind to Australia's low productivity which apparently lagged behind other western economies and that, once the export price boom passed, the nation would find itself in a familiar set of difficulties. So it proved.

Copland was, moreover, apprehensive about the possibilities of implementing a stabilisation package if the economy needed to be wound back because of an external deficit. By the same token, the old 'pioneering spirit' that kindled Australia's economic development in the past had to be revived. Copland 
identified three matters that needed immediate attention: first, to secure more supplies of coal and other materials; secondly, more housing; and, finally, the need to develop more export potential instead of relying upon the existing staples. This meant ridding the economy of rationing and regulation and setting the sails for growth. Copland's overall recommendation was to develop a general plan to recruit resources that were basic to immediate needs and longterm priorities. It was a classic long-term Keynesian program that shunned short-termism. Copland seemed quite unaware that Coombs also lamented that Australia did not seem to be following the dictates of Keynesian functional finance which underpinned the White Paper. There was too much focus on full employment and too little on inflation. Consequently inflation within the economic system was suppressed by the use of controls.

In 1949, Copland made another telling comment about the fabric of Australia's economic development, drawing attention to the imbalance in production patterns between capital goods and consumption goods, arguing that it was impairing Australia's development. He memorably stigmatised Australia's postwar economy as a 'milk-bar' one, preoccupied with meeting consumption needs rather than overall development. The imbalance could only be rectified by redirecting resources to the basic industries, by allowing more access to foreign borrowing, more immigration, and a longer working week. It remained a perennial issue throughout the 1950s.

Elsewhere Copland adumbrated upon the new social and economic framework for a private enterprise economy and deviated slightly from his long-run bearings. Copland outlined six areas where 'social control' or state activity in various spheres of the economy had been largely beneficial, not only in terms of economic development but also remunerative for the business sector. Those spheres were macroeconomic management and stability; public investment spending; establishment of state-owned utilities; social security and redistribution; arbitration and conciliation; and, lastly, restraints upon the power of monopolies. While he welcomed increasing the degree of social control, Copland believed there was an optimal level of intervention. Copland now felt that Australia, at least, had reached that level and that 'a stay order' on further extensions of state activity was now warranted. More intervention or social justice in the economy, he felt, would enfeeble the entrepreneurial spirit that had made Australia.

There was little support from most of his peers about the need to make fundamental adjustments to the economy to secure long-term growth, productivity and development. The neglect of the younger economists bemused him. Their complaints ignored his heroic efforts to change economic policy in the mid-1930s. Whilst reading Roy Harrod's biography of Keynes, Copland wrote to a friend: 
Still reading Keynes and I remember most of the controversy and the discussion he was involved from the 1920's onwards. A few of us had been working on similar lines and I have somewhere a set of memorandums to the government of NSW from 1932 to 1936 urging with all the persuasion I could muster an expansionist policy, but we could not get past the Commonwealth Treasury. It would be fun to dig them out now and circulate for the younger brethren who still think we are past praying for. I'm sure he [Keynes] would disown Coombs and his school if he was with us now. ${ }^{35}$

Some time later, Copland would suggest that the over-enthusiasm for the Keynesian theory and its extravagant expectations in a theory of full employment would have been disowned by the Master'. Copland was unrepentant about his differences with the younger economists even if he was guilty of overdramatising them.

There was no spring clear-out of the economic mandarins when the Menzies Government came to power in 1949. Coombs remained as governor of the Commonwealth Bank and sought to be within earshot of Menzies. Copland would have some intermittent influence especially with the new Federal Treasurer, Arthur Fadden. Moreover, Copland lobbied to get Roland Wilson into the Treasury as secretary in a bid to counter Coombs' influence over the prime minister.

Copland returned to assailing the economic perfectionists in May 1950 in a speech marking the 25th anniversary of the founding of the Victorian Branch of the Economic Society. He warned how the 'more extreme devotees' of planning were 'much too confident of their ability to control the powerful forces arranged against them'. Apart from an illusion about their omniscience, they had not factored into their analysis the requisite degree of public acceptance needed for the new doctrine, especially from the business sector. Copland feared that the planners would not have the courage to prune expenditure when it was needed most, nor would there be public acceptance for doing so. Maintaining the economy at over-full employment would jeopardise price stability and put pressure on Australia's external account. Finally, acute supply shortages interfered with development while full employment meant that workers had little incentive to raise productivity.

Copland, in addition, sought to redress the social balance within the economy, arguing that the entrepreneurial spirit was still the engine that powered a mixed economy. This signified his embrace of a mild form of corporatism. He reaffirmed his long-held faith in the restorative and civilising powers of public 
investment for economic development and dismissed notions that the increase in public debt would impoverish future generations. Since the early 1930s, Copland had consistently praised the role of public investment as the means to economic recovery from the slump. Now he saw it spearheading Australia's economic development.

In July 1950, in an address entitled 'Problems of an Expanding Economy', Copland demonstrated how he differed from the policy outlook of his contemporaries. With a large-scale immigration policy in train, Copland felt it imperative that policy-makers not be hidebound by the past. More importantly, Australia had to become a high investment economy instead of a high consumption one. The migration program spelt huge outlays in housing and infrastructure, meaning that consumption had to be cut, if necessary, by taxation. The 'motto of the age', he suggested, might be 'Houses before hotels, tractors before motor cars, electricity before refrigeration'. If not cut voluntarily, consumption could be wound back by taxation and some inflation. Copland felt that the attendant risks of becoming a high investment economy, namely, a lack of final demand, would not eventuate, and that Australia could easily revert to a high consumption economy.

The last requirement needed for a rapidly expanding economy was to draw upon foreign supplies of capital goods and, if need be, to access foreign funds to acquire them. Here Copland contemplated a new financial nexus with the United States. He was particularly damning of the 'anti-borrowing psychology' and, with one eye on the stalled Australian National University construction program, he vented his spleen, asking, 'How can you develop this country with picks, shovels and wheelbarrows?' He closed by stating that Australia had to choose between stability and progress. To his mind, the instability that comes with large-scale development must come first. He never wavered on this. Four years later he maintained that ' $[\mathrm{w}] \mathrm{e}$ are apt to concentrate on the instability and to ignore the development, as though a high rate of development and stability were natural bedfellows'. The debate about the scale of Australian post-war immigration mirrored, therefore, the divide between the meek and mild 'planners' and the 'brave' advocates of development.

One of the slogans on which the Coalition had campaigned in the 1949 election was 'to put value back into the pound'. It would come back to bite them. By mid-1950 the Menzies Government was caught by their own inflationary crisis stemming from the Korean War boom reflected in high wool and metals prices. The Chifley Government had unwisely devalued the currency by 30 per cent to align Australia with the sterling bloc. Besides encouraging exports, it led to a speculative inflow of capital in anticipation of revaluation. With a fixed exchange rate, the terms-of-trade boost meant exporters' foreign exchange receipts flowed directly into the monetary system fuelling consumption. 
Apart from poor productivity growth, inflation ensued from the levels of social investment needed to absorb a large immigration intake, along with increased defence spending incurred amidst a full-employment economy.

One solution would have been revaluation, which all Australian economists, bar Copland, recommended. He dismissed the idea, stating that an appreciation would have damaged other exporters and also jeopardised the profitability and development of Australia's manufacturing industries. If Australia really wanted to stifle inflation, it had to resort to more domestic options like monetary tightening. Working through the back channels, Copland's advice might have swayed Wilson and Fadden, though the latter would by definition always uphold rural exporting interests.

The more intelligent expedient to both an appreciation and terms-of-trade boom was to quarantine the wool export bonanza into a price stabilisation fund, which would immobilise spending power and thereby contain its inflationary effect. First outlined in September 1950, some of the fund could also be used for rural betterment. Funds could then be released when the fortunes of wool exporters turned against them. While the Menzies Government adopted a variation of Copland's prescription, implementing a wool stabilisation plan came too late to prevent an inflationary impulse surging through the economy. Ultimately, inflation would be quelled by the collapse of commodity prices, a surge in imports and the so-called 'horror budget' of 1951-52.

In the meantime Copland called for radical measures like Australia leaving the sterling bloc because it aligned Australia's trade with the empire and led to trade discrimination against non-members. He thus called into question the old imperial connection with Britain, believing that Australia should strike out into the Asia-Pacific where its economic destiny lay. Relying upon the British market and the sterling area meant limited export growth and constrained development of the Australian economy. This stand raised eyebrows. When he first raised the idea of an American loan in 1948 to deal with Australia's own dollar shortage, the result of a trade imbalance with the United States, he reported much later that his then critics felt he 'had gone over the edge'. ${ }^{36}$ Australia, he motioned, should leave the sterling area, free up the exchange by means of dollar loans and bargain with the United States for further dollars on the basis of the Australian immigration program, which relieved the refugee problem in Europe. He held that 'the one unused resource' of productivity could break the logjam of competing inflationary pressures, which were the product of the boom in export prices, a huge investment program and the very absence of productivity gains.

Copland returned to a variation of the 'milk-bar economy' theme when his book, Inflation and Expansion (1951), was published. The overriding theme of the 
book of essays was how mixed economies, like Australia, became constrained in meeting their welfare and full employment obligations such that they could not channel enough resources to meet their development aspirations. There was none of the impelling urge there had been in wartime to allocate resources to basic industries. Australia, in particular, faced this imbalance, though it was, Copland stressed, primarily a political problem of collective choice. The logical outcome was inflation, which could only be dealt with by higher productivity.

Given his outspoken views on growth and expansion Copland would have been bemused to find himself singled out by the press and the Australian Labor Party leadership for the Australian economy's maladjustment during 1951-52. In the reaction to Fadden's budget of 1951-52, when a counter-cyclical budget surplus was implemented, the Sydney Morning Herald held Copland, along with other academic economists, responsible. It was a strange line of attack when it was really all the Treasury's handiwork. Wilson had told Fadden shortly after he had been appointed secretary that inflation was out of control and endorsed the deflationary measures taken in the 1951-52 federal budget.

Copland must have felt some sense of vindication, however. For some time he had anticipated the likely anger from Australians unaccustomed to cutting expenditure outlays consistent with fiscal restraint. The commitment to full employment meant that exuberance could only be checked 'in the last resort' by the exercise of 'a measure of restraint for which there was no precedent in the history of Australia'. Such was the prospect presented by Fadden's federal budget.

In an $\mathrm{ABC}$ radio commentary, Copland praised the budget as 'economically sound', 'courageous', and a 'landmark in Australian finance'. The budget strategy of increasing taxes and deferring public works would allow more resources to be channelled towards development and defence. Moreover, the tax imposts could be easily reversed and had a low disincentive effect.

Copland's praise of the budget was not contrived. He saw the circumstances of over-full employment, coupled with inflation, as posing a distinctly new challenge to economists:

But on the problem of preventing undue expansion we have yet to learn a good deal more about technique and still more about how to influence government and public opinion to accept restraints ahead of danger. This was the new task confronting the new generation of economists. If they succeed they will achieve even more than their predecessors. ${ }^{37}$

It was a challenge only partly met.

37 D.B. Copland, 'Economic Study and Public Opinion in Australia: The Role of the Economist', Australian Highway, 34, no. 2 (1952). 
By 1952 Australia faced what Copland called 'the old Adam of the Australian economy' - a liquidity crisis brought about by a deteriorating external account. Wool prices had steadily fallen since April 1951 while there had been a flood of imports resulting from buoyant economic activity. The Menzies Government responded to the challenge by resorting to import licensing.

The announcement resulted in a quite extraordinary attack upon Copland by Australia's new business newspaper, the Australian Financial Review. The editor, Jack Horsfall, penned a front-page story, entitled 'The Dire Economic Consequences of Sir D. B. Copland'. ${ }^{38}$ Horsfall's attack had followed a Copland address, 'The Balance of Payments and Money Incomes in Australia', which had been reproduced in the same paper. Surveying the economic conditions that had led to the government imposing trade controls, Copland concluded that Australia was facing a fundamental disequilibrium which necessitated either devaluation or deflation. Full employment, cheap money, an ambitious development and migration policy and a short-lived export price boom had led Australia to this crisis. The 'grievous expedient' of import controls, Copland argued, did not address the true cause of the malaise. Copland drew vindication from what he had been saying over the past seven years, namely, that economic activity had been run too strongly and that productivity had been falling because of the unbalanced nature of investment and poor work practices. Without sourcing enough foreign capital to keep the expansion going, Copland had already warned that an external deficit was imminent.

In a long public diatribe against Copland's views upon economic expansion, Horsfall pinned the imposition of import controls on Copland's crusade for growth and expansion. Horsfall did not pull his punches:

No single voice has been more responsible than his for bringing Australia to the point where import restrictions were unavoidable. He has persistently plugged the case for unbridled development and unlimited immigration in face of disastrous inflation and the dissipation of overseas funds. ${ }^{39}$

In accusing Copland of pushing the cause for expansion even when Australia had not secured dollar loans and when he had just supported the Fadden budget, Horsfall questioned Copland's reading of the economy. Copland, Horsfall suggested, might have to give away his policy advocacy skills. Few Australian economists have been subject to such front-page denigration in Australia's national press. Horsfall had been a former student of Copland's at the University of Melbourne and differed strongly on the growth parameters needed for Australia.

38 'The Dire Consequences of Sir D.B. Copland', Australian Financial Review, 20 March 1952.

39 Ibid. 
With a life-long interest in rural exports, Copland had long anticipated the problem of the external deficit and bemoaned how Australia's trade pattern was hamstrung by imperial preferences when its development aspirations far exceeded the scale of the 1920s. Australia, for instance, received fixed prices for her wheat, butter and meat in the British market while the bulk of her imports came from there. Copland felt that expedients like credit restriction, import restrictions and special trade arrangements to deal with the yawning trade deficit were only 'playing with the problem' and their ultimate effect would be to dampen the pace of economic development. ${ }^{40}$

With the bursting of the wool export boom Copland sensed a new reality in Australian economic management. Australia was returning to 'traditional policy' of coping with 'the vigorous forces of the outside world' away from a 'naïve' Keynesianism of instruments and controls. ${ }^{41}$ Apart from pursuing full employment, other distortions like the sheltered markets of the sterling bloc, the lack of sectoral balance within the economy, and cheap money were being discarded. All this reminded Australian economic planners that, apart from being compatible with the social milieu, economic policies had to be tailored to fit the fact that Australia was still a small, open, vulnerable economy. With a fixed exchange rate, Australia had to ensure it did not get its price and cost structure out of alignment with the rest of the world. Expanding global trade meant that, for commodity exporting countries like Australia, the long-term prognosis was mostly good. Moreover, with better macroeconomic control over expenditure and the establishment of a viable manufacturing sector, the Australian economy would be more stable than in the past.

\section{The golden age}

The age of the mandarins was the age of Keynes. Two of the mandarins, Coombs and Wilson, had different visions of economic management. Wilson, however, seemed more a big picture man like Copland than Coombs, who focused on short-term macroeconomic management. Both agreed, however, that, with continuous economic growth, it was inflation rather than unemployment that had to be monitored. Academic economists reinforced this view and occasionally sought to impress a point. In a manifesto issued in February 1956, 'The outlook for the Australian economy', eight leading professors of economics recommended an increase in taxation and interest rates in a bid to dampen 'spendthrift prosperity' and generate more savings. As government investment spending had not been rising rapidly, and because there was a desperate need

40 'Copland Urges a Grand Course', Australian Financial Review, 12 December 1951, 12.

41 D.B. Copland, 'The Australian Post-war Economy: A Study in Economic Administration', Canadian Journal of Economic and Political Science, 20, no. 4 (1954), 436-7. 
to implement various infrastructure projects, the manifesto opposed cuts in government expenditure. It also dismissed direct controls as a solution for excess demand. Not long afterwards, the government brought down a mini-budget of deflationary measures to strike at the 'root cause' of Australia's current account deficit problem.

Upon returning home from a diplomatic posting in 1956, Copland was amazed to find that the main policy debate among academic economists was still whether Australia was growing too fast. Not for the first time, he preached adventure and expansion. He was convinced that economic progress since 1953 had been 'relatively sound and vigorous' and in no need of restraint. ${ }^{42}$

Neither the Treasury nor his academic colleagues shared his optimism. The new generation of economists, he continued, worshipped the false god of stability' when 'there was no future in stability' ${ }^{43}$ It was much better, Copland reasoned, to be discussing growth and expansion 'than to be worrying about the problems of devastating depression' of 25 years ago. Copland was concerned that the authorities were going to suppress expansion because of worries about inflation. Heinz Arndt represented academics expressing concern that Australia's creeping inflation rate, if left unchecked, would compound economic difficulties, particularly with the external account, in the near future. Copland was not just on the outer but fast losing his credibility. Coombs warned that community passivity about tolerating 'creeping inflation' would build into something monstrous.

Copland remained unrepentant and urged policy-makers to push on with 'the adventure of economic expansion on the grand scale whilst enduring the restraints that are necessary for its success'. This meant that consumption and the obsession with security and employment took a lower priority. Ideally, the title of his co-edited anthology, The Conflict between Stability and Expansion (1957), encapsulated the dilemma facing Australian economic policy-makers.

He repeated his prescription of expansion before stability in one of his last scholarly contributions. After discussing the conflict between growth and stability Copland listed the policy settings needed for Australia to focus upon the former. Fiscal policy, perhaps in the form of higher personal income tax, would channel a higher level of savings into capital formation, which, in turn, would realign the balance between consumption and investment. This policy, if successfully implemented, would make it unnecessary to resort to a credit squeeze to ensure proper distribution of resources between consumption and investment.

42 D.B. Copland, 'The Australian Economy: A New Look', Economic Record, 33, no. 65 (1957), 141-52.

43 D.B. Copland to W.S. Robinson, 23 January 1961, Copland Papers, NLA MS 3800, Box 11, file 85. 
Despite the warning about the build up of excessive demand there was to be another stop-go episode that was almost comical. In a bid to free up supplies Roland Wilson urged the new treasurer, Harold Holt, to abandon import controls in February 1960. There was an immediate surge in imports, which led to a deficit on the trade account. In November 1960, Holt had to announce a minibudget, which amounted to Australia's first post-war credit squeeze. 'Holt's Jolt' quickly turned into recession. Copland told Fadden, who had only just retired as treasurer, that the current policy pronouncements seemed to him one of 'the most confused' he had ever witnessed. ${ }^{44}$ He argued that import controls should not have been relaxed when Australia's export prices had fallen 25 per cent since 1952. Now Copland queried how a credit squeeze could ever promote growth and development. ${ }^{45}$ He felt that the Commonwealth Government had become easily intimidated by a slight increase in inflation and a balance of payments deficit problem. With his friend and mentor, W.S. Robinson, Copland dismissed the threat of inflation, vouching that he would rather have a slight lift in prices than dampen economic growth. ${ }^{46}$ Menzies was unrepentant about the credit squeeze:

Nobody can get rid of inflationary booms without treading on someone's corns. It is the duty of the practical statesman to select the corns and not be afraid of treading on them. To achieve this I must be content to annoy thousands. ${ }^{47}$

In 1963, Copland turned his mind towards economic planning and growth targets but no one in the bureaucracy (except perhaps Crawford) was much interested. He rather crudely lamented to Robinson:

It is very funny that nobody in Australia is seriously interested in growth: but then we must remember that we have among the economists the Seven Dwarfs, who naturally would hardly be interested in growth. ${ }^{48}$

Some of the 1960s imbroglio was repeated the next decade with the Whitlam Government but this time it spelt the end of the Keynesian era. It was elected against a backdrop of a fully employed economy and a balance of payments in surplus. The economic bounty suggested that it would be practical to implement Whitlam's election promises. The only apparent bugbear was that their predecessors had allowed an inflationary problem to linger. Annual inflation rates of 7.3 per cent were significant for the time, coming from both domestic

\footnotetext{
44 D.B. Copland to Sir A. Fadden, 15 December 1960, Copland Papers, NLA MS 3800, Box 11, Series 1, Folder 88.

45 'The Credit Squeeze and the Balance of Payments: A Key Problem in Economic Statesmanship', Sydney Mirror, 15 February 1961.

46 'Import Controls Best', Age (Melbourne), 11 May 1961.

47 Cited in A. Millmow, 'Eye on the Money', in A. Cornell, ed., The Best Australian Business Writing 2012 (Sydney: New South Publishing, 2012), 222.

48 D.B. Copland to W.S. Robinson, 21 March 1963, Copland Papers, NLA MS 3800, Box 12.
} 
cost pressures and rising import prices. By refusing to deal with average wage increases of over 10 per cent for 1972 and then by not revaluing, the McMahon Government exposed the economy to underlying tensions. Whitlam was committed to significant social reform through government spending despite these economic clouds on the horizon. Gerald Firth had identified the incipient problem of stagflation in May 1972. He recommended greater wage discipline to disarm it. ${ }^{49}$

With the economy in boom through 1973, the Federal Treasury, aghast at the growth in outlays, advised caution. In his first budget as treasurer, Frank Crean allowed the inflationary problem to loom larger by allowing a significant growth in federal outlays financed by Treasury notes and cash balances with the central bank. Fred Gruen, Whitlam's economic adviser, later recalled that the demand pressures building in 1973-74 were of 'a greater intensity' than anything since the end of the Second World War. A 25 per cent tariff cut and a further revaluation helped alleviate matters by diverting demand pressures to imports. There was also price control aimed at big business in the form of the Prices Justification Tribunal, which might have reduced the inflation rate from what it otherwise would have been. However, on the fiscal policy front, Crean was not sufficiently tough enough to exercise restraint of the growth on outlays which the Treasury felt advisable.

With fiscal policy already prescribed, the Labor Government endeavoured to contain the inflation problem by sharply increasing interest rates. The subsequent credit squeeze went on for far too long and thus led to the subsequent recession. Firms and businesses were caught short, having built up their stocks and over-ordered to catch up with a booming domestic demand. Given the sudden weakening of markets, Australian firms could not easily pass on wage and other cost increases.

The quadrupling of oil prices by the Organisation of Petroleum Exporting Countries (OPEC) cartel in the year from December 1973 exacerbated Australia's domestically generated inflation and unemployment problems. Continuing strong wages expansion in the first two years of the Labor Government further facilitated a booming economy. As a result, the wages' share of national income rose at the expense of profits.

The 1974-75 budget, described by Crean as 'a budget of many hands', was an inappropriate response to the situation. By this time the Treasury had been marginalised because the government had lost faith in its approach. Cairns replaced Crean at the end of 1974 largely because the latter was perceived as dominated by the Treasury. The Labor Party caucus did not feel that containing

49 'The Problem of Stagflation: Unemployment with Rising Prices', May 1972 Public lecture at University of Tasmania, Firth Papers, NLA. 
inflation should be the priority when unemployment was rising. This budget was therefore unorthodox in a period of very high inflation, providing urban renewal to deprived areas, some income tax relief and a 33 per cent increase in government outlays, together with increased taxes for the business sector. The idea was to encourage union agreement for wage restraint, thus limiting the pass-on of international inflation through cost pressures in Australia.

Cairns received a missive from the governor of the Reserve Bank of Australia, Sir John Phillips, with his 'solution' to stagflation. Phillips was an early convert to monetarism and had been tracking money supply growth. The malaise in the business sector, Phillips felt, was deep-seated in character and could not be resolved by a boom in spending led by government expenditure. Phillips felt it advisable that government expenditures and the rate of monetary expansion be reined back as inflation was badly disrupting business planning. Apart from keeping wage pressures under check, reducing the rate of government spending would restore confidence to the private sector. ${ }^{50}$

Phillips' advice stemmed from the Reserve Bank of Australia's 1973 Annual Report that was noticeable for joining with the Treasury in arguing that inflation mattered more than unemployment. The dominant culture amongst the RBA's economists had recently become monetarist. It was symbolised the year before (1973) by the presence of a leading English monetarist, Michael Parkin, within the Bank's Research Department. ${ }^{51}$

Economists and senior officials within the RBA were the first to accept 'inflationary expectations' as a significant factor within the policy domain. Treasury economists, too, accepted the importance of inflationary expectations before comparable acknowledgement by their academic brethren. Despite its misgivings about some of Milton Friedman's work, the Treasury became more monetarist in outlook following the experience of the late 1973 credit squeeze.

In April 1975, a small-statured man who was neither a dwarf nor a mandarin arrived in Canberra. It was the father of monetarism, Milton Friedman. He had come to administer the last rites of Australian Keynesianism. The message he hammered home was that the choice between inflation and unemployment disappears when inflation is out of control; any action to create more jobs merely adds to inflationary expectations and, in turn, a further rise in unemployment. It was a new wisdom for a new age - full employment was replaced by a concept called NAIRU (the non-accelerating inflation rate of unemployment).

50 Sir J. Phillips to J.F. Cairns, 18 December 1974, National Archives of Australia (NAA) A5931 CL 155.

51 'Reserve Bank Backs the Treasury Line', Australian Financial Review, 28 August 1974. 


\section{Retrospect}

Despite two recessions, stop and starts, trade deficits and policy errors, the age of Keynes was, to quote the economic historian Angus Maddison, 'a golden age'. It was thus for Australia as it was for other western countries. Despite Copland's protestations about not growing fast enough, Australia still registered an average growth rate of 4.7 per cent during the period 1945-73, higher than most comparable industrialised countries. During the post-war era Australia's population grew on average at 2.5 per cent, one of the highest growth rates in the world. Inflation averaged 4.6 per cent over the same period. In the 1970s, macroeconomic performance deteriorated markedly as growth fell to 3.1 per cent while inflation soared to an average of 9.7 per cent. ${ }^{52}$

While the post-war period enjoyed propitious factors like reconstruction, pentup demand and the liberalisation of international trade, Ian MacFarlane also notes that there was widespread restraint in economic behaviour along with governments committing themselves to full employment and robust economic growth. There was a high savings rate and little reliance upon foreign savings. MacFarlane says fiscal and monetary policies were adjusted to smooth the business cycle but this did not mean that fiscal policy was too expansionary. If anything, demand management was restrained. In the 12 years between 1961 and 1973, the budget was, on balance, in surplus. In the earlier period, 1950 until the 1970s monetary and fiscal policy could not be too expansionary without threatening inflation, the balance of payments or the exchange rate. When, moreover, there was a recession, there was also a quick recovery. While in recent times there has been talk of 'The Great Moderation' in macroeconomic performance from the mid-1990s onward without any explicit Keynesian economic management, one should point out that it only lasted for less than half the period known as the Keynesian golden age. 
This text is taken from The Seven Dwarfs and the Age of the Mandarins: Australian Government Administration in the Post-War Reconstruction Era, edited by Samuel Furphy, published 2015 by ANU Press, The Australian National University, Canberra, Australia. 